Dariusz Kubinowski

Uniwersytet Szczeciński

\title{
ISTOTA
}

\section{JAKOŚCIOWYCH BADAŃ PEDAGOGICZNYCH \\ - WPROWADZENIE}

Przełom XX i XXI wieku to okres intensywnego rozwoju - ilościowego i jakościowego - uprawiania badań jakościowych $w$ naukach pedagogicznych w Polsce. Imponująco wzrosła bowiem liczba realizowanych pedagogicznych projektów badawczych z zastosowaniem metod jakościowych, a także stopniowo $w$ rezultacie konstruktywnej krytyki i intencjonalnego pogłębiania świadomości metodologicznej pedagogicznych badaczy jakościowych - podnosi się ich poziom warsztatowy, co znajduje wyraz $w$ wielu kolejnych, coraz bardziej zaawansowanych publikacjach naukowych [szerzej zob. Kubinowski 2013].

Badania jakościowe uprawiane na gruncie rodzimej pedagogiki, $w$ rezultacie nabierania dojrzałości naukowej, stały się autonomicznym, swoistym polem działalności akademickiej (choć nie tylko), realizowanej we współpracy wielu uczonych utożsamiających się z humanistyczną filozofią człowieka leżącą u ich podstaw, wykorzystujących różnorodność i kreatywność metodyki ich realizacji $w$ praktyce badawczej oraz stosujących adekwatne kryteria ich ewaluacji. Do bliższego zainteresowania się nimi oraz podejmowania prób ich wykorzystania $w$ rozwiązywaniu istotnych i aktualnych problemów badawczych skłania wielu pedagogów akademickich - szczególnie młodszej generacji - towarzysząca ich najnowszej historii, synergia poznawania i zmieniania, czyli nastawienie na służenie dobru człowieka, zarówno $w$ aspekcie korzyści poznawczych jak i projektowania konkretnych oddziaływań proosobowych, prospołecznych, prohumanistycznych etc. oraz projektów emancypacyjnych, transformacyjnych, zaangażowanych etc. 
Wraz z „eksplozją” zainteresowania i praktykowania badań jakościowych na gruncie współczesnych nauk pedagogicznych w naszym kraju, czasami pojawiają się nieporozumienia, błędy, nadużycia etc. w rozumieniu i określaniu ich istoty, zarówno przez ich reprezentantów i zwolenników, jak i ich przeciwników i krytyków oraz autorów, którzy mimo że podejmują próby wypowiadania się na ich temat, a nawet deklarują ich stosowanie $w$ swoich badaniach, to nie posiadają wystarczającej wiedzy, także z literatury światowej, aby ich opracowania na ten temat uznać za kompetentne. Utrudnia to wydatnie rzeczową dyskusję naukową i czasami czyni ją tendencyjną, o wyraźnym zabarwieniu ideologicznym. Spróbujmy zatem $w$ tym miejscu powtórzyć i syntetycznie wyeksponować to, jak rozumiemy istotę jakościowych badań pedagogicznych, wskazując na cechy konstytutywne kolejno takich kategorii metodologicznych jak: „badanie”, „badanie jakościowe”, „badanie pedagogiczne” i wreszcie „jakościowe badanie pedagogiczne”. W szerszym zakresie argumentacja na rzecz przyjęcia proponowanego tu rozumienia tych kategorii została przedstawiona $w$ monografii Jakościowe badania pedagogiczne - filozofia, metodyka, ewaluacja [Kubinowski 2010, 2011].

Najogólniej rzecz ujmując badanie to metodyczne eksplorowanie rzeczywistości ukierunkowane na poszukiwanie nowej wiedzy. Angielski termin research - oznaczający „badanie” - pochodzi od łacińskiego re-circere. Re- we wszelkich złożeniach oznacza powtarzanie jakiejś czynności. Czasownik circere natomiast odnosi się do krążenia wokół jednego punktu. Stąd wszelkie badanie można rozumieć jako wielokrotne, stale pogłębiane wglądy, eksplorowanie danego zjawiska, sytuacji, kontekstu czy terenu [Giarelli, Chambliss 1988: 32]. Badanie ma zatem charakter bezpośredniego doświadczenia przez badacza ściśle określonego przedmiotu badań, polegającego na wielokrotnie powtarzającym się wnikaniu zmysłowym i pozazmysłowym $w$ jego istotę i jakości, z uwzględnieniem procedury badawczej opartej na modelach kołowych. Takie rozumienie badania odsyła nas wprost do Gadamerowskiej idei doświadczenia hermeneutycznego jako procesu poznawczego. W terminologii niemieckiej pojęcie erfahren tłumaczone jest jako „doświadczać”, a dosłownie znaczy „przejeżdżać”, natomiast verstehen tłumaczone jako „rozumieć”, dosłownie oznacza „przystawać”. Zatem doświadczenie hermeneutyczne to poddanie się działaniu badanego zjawiska poprzez osobiste jego odczucie i podjęcie próby dopasowania się do jego istoty i jakości $w$ procesie 
poznawania, nastawionego na pogłębione jego rozumienie [Gadamer 1993: 292, 324-337].

Aby doprecyzować istotę i zakres badań jakościowych, należy zwrócić uwagę, że $w$ angielskiej terminologii z zakresu metodologii jakościowych obok pojęcia „research” występują jeszcze dwa zbliżone określenia, a mianowicie: „study” i „inquiry”, które można przetłumaczyć jako „studium” i „dociekanie”. Przyjmując, że łącznie te trzy terminy mogą porządkować przeróżne próby czynności poznawczych, zaproponowałem wprowadzenie odróżnienia badań jakościowych od studiów i dociekań jakościowych. Najszerszy zakres znaczeniowy ma termin „dociekania jakościowe”, gdyż obejmuje wszelkie - naukowe i pozanaukowe poznawanie rzeczywistości z zastosowaniem myślenia jakościowego, a zatem studia i badania jakościowe, ale także sztukę, dziennikarstwo, krytykę, ewaluację, analizy prawnicze i polityczne, edukację, działanie etc. „Studia jakościowe” mają charakter naukowy i obejmują zarówno studia teoretyczne, refleksje filozoficzne, analizy historyczne, interpretacje hermeneutyczne, wglądy fenomenologiczne i heurystyczne etc., jak i badania jakościowe. Wobec powyższego termin „badania jakościowe" odnosi się $w$ tym ujęciu wyłącznie do empiryczno-analitycznych czynności poznawczych opartych na bezpośrednim, osobistym doświadczeniu. Badacz osobiście gromadzi materiał empiryczny i poddaje go analizie oraz interpretacji, stosując na wszystkich etapach realizacji projektu badawczego adekwatne metody jakościowe.

W literaturze przedmiotu znajdziemy wiele prób zdefiniowania oraz określenia cech konstytutywnych badań jakościowych. W tym miejscu odwołam się tylko do jednej z nich. Michael Q. Patton uznał za cechy swoiste badań jakościowych następujące wyróżniki:

- naturalistyczny charakter dociekań, czyli dopasowanie się badacza i stosowanych

przez niego metod do istoty przedmiotu badań bez dokonywania jego przekształceń za pomocą narzędzi badawczych oraz podejmowanie prób dokumentowania i analizowania materiału empirycznego $w$ oryginalnej postaci;

- analiza indukcyjna, czyli ograniczenie prekonceptualizacji projektu badawczego do niezbędnego minimum, a następnie generowanie rezultatów prowadzonych badań sukcesywnie $w$ miarę pozyskiwania i analizowania kolejnych partii materiału empirycznego; 
- perspektywa holistyczna, czyli otwartość na wszelkie docierające do badacza dane empiryczne o istotnym znaczeniu $w$ realizacji celów poznawczych projektu badawczego oraz próba całościowego rozumienia i opisywania badanego fragmentu rzeczywistości;

- dane jakościowe, czyli autentyczny materiał empiryczny, gromadzony przez badacza w celu udokumentowania autentycznych jakości badanej rzeczywistości bez dokonywania operacji przekształcania ich w ekwiwalenty liczbowe czy w inny sposób zmieniające ich status ontologiczny;

- osobisty, bezpośredni kontakt, czyli wymóg intensywnego „zanurzenia” się badacza $w$ materiale empirycznym i osobistego doświadczania jego oddziaływania na własnej cielesności i duchowości;

- ujęcie dynamiczne, procesualne, czyli branie pod uwagę nieuchronnej diachroniczności badanej rzeczywistości humanistycznej i społecznej oraz uwzględnianie $w$ analizie przeszłych i przyszłych jej przemian;

- orientacja na unikalny przypadek, czyli stosowanie w praktyce badawczej ontologii niepowtarzalności, różnorodności, wieloznaczności etc. badanych podmiotów (osobowych czy instytucjonalnych) i unikanie atomizowania ich niezbywalnej integralności $w$ toku analizy;

- wyczulenie kontekstualne, czyli uwzględnianie wszystkich istotnych kontekstów badanej rzeczywistości na etapie gromadzenia i analizy materiału empirycznego oraz rezygnacja z dekontekstualizacji jego interpretacji;

- empatyczna neutralność, czyli z jednej strony wczuwanie się badacza w przekazy empiryczne konstruowane przez badanych, a z drugiej - powstrzymywanie się od eksponowania własnych przekonań, sądów czy wartości w toku ich bezpośredniego dokumentowania, analizowania i interpretowania;

- elastyczność projektu badawczego, czyli emergentne dopasowywanie założeń

badawczych i wszelkich czynności badacza do bieżących sytuacji poznawczych jako rezultatu metodycznego podejmowania decyzji, wynikających z kolejnych etapów gromadzenia i analizowania materiału empirycznego [Patton 1990: 39-62].

Termin „pedagogika” jako nazwa dyscypliny naukowej uprawianej w Polsce wywodzi się z niemieckojęzycznego obszaru kulturowego. Zostało do nas przeniesione $w$ czasach, kiedy nauka niemiecka pełniła rolę wiodącą whumanistyce światowej. Współczesna polska pedagogika to hybryda 
przebogatych tradycji i propozycji własnych oraz zapożyczeń i adaptacji dokonań pochodzących ze źródeł niemieckich i angloamerykańskich, a także innych obszarów kulturowo-językowych. Swoiste piętno wycisnęła na niej pedagogika socjalistyczna, uprawiana w okresie Polskiej Rzeczypospolitej Ludowej. Po roku 1989 rozwijała się intensywnie $w$ pełnej otwartości na światowe dokonania swoiście rozumianych $w$ różnych krajach nauk o edukacji/wychowaniu, wnosząc do międzynarodowego dorobku swój znaczący i znaczny wkład. Zaznaczyć jednak należy, że $w$ języku angielskim nie występuje termin wprost odpowiadający pedagogice jako nazwie dyscypliny naukowej. W uniwersytetach brytyjskich i amerykańskich używa się terminu „education”, zarówno jako określenia praktyki kształcenia, jak i dyscypliny naukowej zajmującej się jej badaniem. Jednak tłumaczenie polskiej nazwy „pedagogika” jako „education” nie oddaje istoty rzeczy z uwzględnieniem kontekstów kulturowych. Błędne jest także używanie $w$ tym wypadku angielskiego „pedagogy”, zwłaszcza że w pedagogicznej terminologii polskiej od początku XX wieku używane jest pojęcie „pedagogia/pedagogja”, w odróżnieniu od nazwy „pedagogika”. Oba terminy służyły i nadal służą do określania czegoś innego. Tłumaczenie pojęcia „badanie pedagogiczne” na język angielski jako „educational research” także nie spełnia podstawowego warunku idiomatycznego odwzorowania semantycznego. Teoria i praktyka pedagogiczna $w$ znaczeniu nadawanym $w$ polskiej terminologii naukowej jest pojęciem znacznie szerszym aniżeli teoria i praktyka edukacyjna, gdyż oprócz edukacji instytucjonalnej, formalnej, intencjonalnej etc. obejmuje wszelkie procesy wychowawcze, edukacyjne, kształtujące, formujące człowieka w ciągu całego życia i w pełnym jego spektrum. Te wszystkie niuanse językowe mają swoje daleko idące konsekwencje $w$ sytuacjach obustronnych przekładów, które oprócz kompetencji translatorskich wymagają od ich autorów także podstawowej wiedzy pedagogicznej.

W 2008 roku zaproponowałem, aby za badania pedagogiczne uznawać te badania naukowe, które spełniają dwa nakładające się na siebie warunki. Po pierwsze chodzi o ich przedmiot, którym jest szeroko rozumiane wychowanie (edukacja, kształcenie, formowanie) człowieka oraz jego różnorodne konteksty. Po drugie zaś o posłużenie się przez badacza perspektywą pedagogiczną, która obejmuje trzy dopełniające się wymiary dociekań: (1) opis, analiza, interpretacja, rozumienie/wyjaśnianie badanych zjawisk i procesów wychowawczych/ 
edukacyjnych oraz ich kontekstów; (2) ich wartościowanie humanistyczne, przy założeniu, że humanizm jest kategorią dyskursywną; (3) odniesienie wyników badań i ich wartościowania do kategorii potencjalności człowieka, czyli poszukiwania i projektowania możliwej konstruktywnej zmiany proosobowej, prospołecznej, prohumanistycznej etc. [Kubinowski 2008: 47-56].

Dodać wypada w tym miejscu, że badania pedagogiczne nie mogą być utożsamiane ze wszystkimi badaniami prowadzonymi przez pedagogów akademickich. Zdarza się tak, że mimo iż autorem jest pedagog akademicki, to jego badania nie mają charakteru pedagogicznego. Kiedy indziej zaś charakter pedagogiczny posiadają niektóre badania prowadzone przez przedstawicieli innych aniżeli pedagogika dyscyplin naukowych, mimo że ich autorzy sami nie definiują ich jako pedagogicznych. O pedagogiczności określonego projektu badawczego decyduje spełnienie dwóch wymienionych wyżej warunków, a nie afiliacja dyscyplinarna.

W konsekwencji dochodzimy do kluczowego terminu jakościowych badań pedagogicznych. Są to badania, które łączą synergicznie wszystkie wyżej wymienione cechy, zarówno badań jako takich, jak i badań jakościowych oraz badań pedagogicznych. Dodać należy, że nie posiadają one jakichś wyjątkowych, swoistych, typowych tylko dla siebie metod badawczych. Jakościowe badania pedagogiczne wpisują się w spektrum badań jakościowych w ogólności, korzystając z doświadczeń ich uprawiania na gruncie nauk humanistyczno-społecznych oraz wielu dyscyplin naukowych lokujących się poza nimi, ale dotyczących zawsze człowieka/ludzi i jego/ich świata/światów. Perspektywa pedagogiczna - wyraźnie manifestowana w większości badań jakościowych uprawianych przez pedagogów posiada swoją wyjątkową specyficzność. Jest ona znaczącym wkładem środowiska pedagogów akademickich do metodologii nauk, dającym się najpełniej docenić $w$ inter- i transdyscyplinarnym horyzoncie wytwarzania wiedzy naukowej o człowieku i jego wychowaniu. Synergia badań jakościowych i perspektywy pedagogicznej pozwala na unikalne $w$ świecie nauki osiąganie korzyści poznawczych i aplikacyjnych specyficznego rodzaju. Dzięki tym podejściom badawczym możliwe staje się poszerzanie i pogłębianie oglądu rzeczywistości humanistycznej i społecznej dokonywanego na gruncie innych dyscyplin naukowych i dziedzin wiedzy. 
Od 2016 roku rozpoczynamy wydawanie naukowego czasopisma on-line pod tytułem „Jakościowe Badania Pedagogiczne”. Nasze czasopismo zasadniczo ma charakter metodologiczny oraz funkcjonuje $w$ ramach ruchu Open Access i na jego zasadach. Wydawcą czasopisma jest Wydział Humanistyczny Uniwersytetu Szczecińskiego, Komitet Redakcyjny współtworzą pracownicy naukowodydaktyczni Instytutu Pedagogiki tegoż Uniwersytetu, a w skład Rady Naukowej wchodzą reprezentanci różnych ośrodków akademickich z całego kraju.

Mając na uwadze istnienie wielu zagranicznych czasopism naukowych całościowo dedykowanych badaniom jakościowym $w$ edukacji/pedagogice, celowo koncentrujemy się przede wszystkim na wspomaganiu intensywnego rozwoju jakościowych badań pedagogicznych w Polsce. Wszystkie opracowania są zatem publikowane wyłącznie po polsku, wpisując się $w$ rodzimą wykładnię uprawiania badań jakościowych na gruncie nauk pedagogicznych, jednak z wyraźnym uwzględnieniem dorobku światowego.

Wszystkie publikowane $w$ naszym piśmie teksty dotyczą - wprost lub pośrednio - różnorodnych badań jakościowych uprawianych na gruncie nauk pedagogicznych lub innych dziedzin i dyscyplin naukowych, o ile uwzględniana jest $w$ nich perspektywa pedagogiczna. W poszczególnych numerach publikujemy oryginalne artykuły naukowe dotyczące wybranych aspektów jakościowych badań pedagogicznych w ogólności oraz poszczególnych ich tradycji, metod, aspektów etc., mieszczące się $w$ ramach szeroko rozumianych dociekań metodologicznych; komunikaty z aktualnych badań jakościowych osadzonych $w$ naukach pedagogicznych lub pedagogicznie zorientowanych; recenzje naukowe najnowszych publikacji z zakresu jakościowych badań pedagogicznych oraz sprawozdania z bieżących konferencji naukowych i innych wydarzeń przyczyniających się do ich upowszechnienia i zaawansowania, jak również okazjonalnie opracowania naukowe innego rodzaju mieszczące się $w$ tak określonym zakresie przedmiotowym.

Kierując się zasadą idiomatyczności, jako kluczową dla wszelkich badań jakościowych, nie ustanawiamy stałych działów naszego czasopisma, dodatkowo zachęcając do zmierzenia się z gatunkami opracowań naukowych o nietypowej 
formule. Schematyzm jest zaprzeczeniem kreatywnego myślenia i działania. Jeśli uprawianie nauki ma być płodną twórczością humanistyczną, to musi unikać mechanistycznych schematów, we wszelkich jego postaciach. Czasami badacze jakościowi - szczególnie początkujący - oczekują na gotowe wzorce, sprawdzone metody, instruktywne reguły, podręczniki metodyczne opisujące krok po kroku jak w książce kucharskiej - jakie czynności i w jaki sposób należy zaplanować i zrealizować $w$ ramach projektu badawczego, aby zapewnić sobie sukces, jak „po dotknięciu czarodziejską różdżką". Schematyzm pojawia się także czasami w wytycznych redakcyjnych niektórych czasopism, kiedy wymaga się od wszystkich jednolitej struktury artykułów napisanych na podstawie badań empirycznych czy ścisłego ujednolicenia wszelkich wymagań edytorskich. Zdarza się i tak, że redaktorzy techniczni zatrudniani przez wydawnictwa „niszczą” osobiste style autorskie $w$ imię rzekomej dbałości o poprawność językową tekstów i obowiązujące $w$ danym środowisku normy publikacyjne. Mając za sobą wiele takich doświadczeń, proponujemy programową rezygnację z ujednoliceń tego typu, traktowanych przez nas jako szkodliwy schematyzm blokujący rozwój współczesnej humanistyki naukowej. Wobec tego nie ustanawiamy także unifikujących norm edytorskich, dotyczących na przykład objętości opracowań, systemu przypisów czy tym bardziej struktury i zawartości opracowania. Nie oznacza to jednocześnie, że $w$ ten sposób zamierzamy tolerować chaos formalny i błędy redakcyjne. Jesteśmy głęboko przekonani, że każdy kompetentny autor wie najlepiej, jaki system przypisów wybrać, jaką strukturę zastosować oraz jak wykorzystać określone normy edytorskie, aby adekwatnie wzmocnić idiomatyczność swojej prezentacji poprzez odpowiedni dobór i poprawne użytkowanie ściśle określonego formatu redakcyjnego. Przyjmujemy jednocześnie za niezbywalny standard pomyślne przejście krytycznej, wymagającej procedury recenzenckiej przez wszystkie zamieszczane $w$ naszym czasopiśmie opracowania.

Pojawienie się i rozwinięcie $w$ ostatnich latach idei humanistyki cyfrowej wzmocniło wysiłki tych badaczy jakościowych, którzy od dawna starali się zmienić proporcje między słowem a innymi formami przekazu $w$ opracowaniach naukowych. Rozwój nowych mediów wydatnie przyczynił się do powstania dotąd niespotykanych możliwości technologicznych zasadniczego przeformatowania tradycyjnego raportu badawczego i opracowania naukowego. Słowa zapewne pozostaną nadal najważniejszym nośnikiem treści naukowych, jednak mogą 
i powinny być dopełnione przekazem niewerbalnym za pomocą różnorodnych mediów. Zabieg taki pozwala często lepiej wyrazić sensy i znaczenia w sposób idiomatyczny, dla których słowa będą tylko nieadekwatnym uproszczeniem. Oczekujemy zatem na opracowania multimedialne, a szczególnie na wykorzystywanie możliwości takich gatunków naukowych, które multimedialność czynią swoją istotą. Zachęcamy także do nadsyłania nie tylko werbalnych i multimedialnych tekstów $w$ tradycyjnym rozumieniu, ale także opracowań hipertekstualnych i hipermedialnych, które dziś stanowią nowoczesny format publikacji naukowych szczególnie przydatnych $w$ prezentacji badań jakościowych. W rezultacie rewolucji technologicznej doczekaliśmy się raportu naukowego najnowszej generacji $w$ postaci opracowania hipermedialnego zamieszczanego $w$ Internecie. Istotną częścią tej transformacji stały się czasopisma on-line, funkcjonujące $w$ ruchu naukowym Open Access. Mamy nadzieję, że jednym z nich stanie się trwale czasopismo „Jakościowe Badania Pedagogiczne”. Zachęcamy więc wszystkich Autorów do proponowania nam wykorzystywania najnowszych rozwiązań technologicznych, włączania do swoich tekstów reprezentacji muzycznych, fotograficznych, plastycznych, filmowych, teatralnych, tanecznych, poetyckich, a także zaskakiwania nas, i następnie naszych Czytelników, kreatywnością naukowo-humanistyczno-technologiczną.

Zapraszamy do nadsyłania tekstów, mieszczących się $w$ tak określonych ramach programowo-edytorskich naszego czasopisma, do publikacji na jego łamach. Informacje redakcyjne znajdują się $w$ poszczególnych działach na stronie internetowej https://wnus.edu.pl/jbp 


\section{Bibliografia}

Gadamer H.-G., 1993, Prawda i metoda. Zarys hermeneutyki filozoficznej, Kraków: Inter Esse.

Giarelli J. M., Chambliss J. J., 1988, Philosophy of education as qualitative inquiry, [w:] Sherman R. R., Webb R. B. (red.), Qualitative research in education: focus and methods, London - New York - Philadelphia: The Falmer Press.

Kubinowski D., 2008, Wychowanie i jego konteksty w perspektywie pozapedagogicznej i pedagogicznej, [w:] Rubacha K. (red.), Konceptualizacje przedmiotu badań pedagogiki, Kraków: Oficyna Wydawnicza „Impuls”.

Kubinowski D., 2010, 2011, Jakościowe badania pedagogiczne: filozofia - metodyka - ewaluacja, Lublin: Wydawnictwo Uniwersytetu Marii Curie-Skłodowskiej.

Kubinowski D., 2013, Idiomatyczność - synergia - emergencja. Rozwój badań jakościowych w pedagogice polskiej na przełomie XX i XXI wieku, Lublin: Wydawnictwo „Makmed”.

Patton M. Q., 1990, Qualitative evaluation and research methods, Newbury Park - London - New Delhi: Sage Publications. 